\title{
A SUMMARY OF THE MEMBERS OF THE GENUS CHILOSIA, MEIG., IN NORTH AMERICA, WITH DESCRIPTIONS OF NEW SPECIES.
}

BY W. D. HUNTER, ASSISTANT IN ENTOMOLOGY, UNIVERSITY OF NEBRASKA.

Chilosia signatiseta, n. sp.

Eyes bare, arista plumose, scutellum with long hairs on the margin, third antennal joint very large, bright yellowish-red. Legs black.

Male.-Front prominent, opaque, strongly sulcate medially, very indistinctly punctulate, long black pilose. Face shining black, pollinose on the sides and pilose on orbital margin below; below the antennæ deeply concave to the tip of the tubercle, thence gently concave to the epistoma. Tubercle projecting somewhat beyond the base of the third antennal joint, round. Cheeks shining, sparsely whitish pilose. Ocellar area black pilose. Eyes metallic. First antennal joint black, second dark reddish-brown, third bright yellowish-red, very large, subquadrate, with the lower outer corner rounded, upper corner obtusely pointed. Arista basal, black, incrassate, densely plumose. Dorsum of the thorax very lightly punctate, shining greenish-black, abundantly whitish pilose (viewed from in front) mixed with black in the middle, longer posteriorly. Scutellum lightly punctate, abundant long black pilose, with a few light hairs intermixed. Pleura abundant long whitish pilose. Abdomen with the sides almost parallel, short sparse yellowish pilose, more abundant on the sides, where it is intermixed with a few black hairs. First segment entirely opaque, second and third except on the lateral margins, fourth entirely, bright shining greenish. Legs black, all the knees reddish; pile in most reflections black; on the under side of all the tarsi and the anterior tibiæ, golden in some reflections. Wings hyaline, veins dark brown, apical cross-vein almost straight, without stump. Length, $7 \mathrm{I} / 2 \mathrm{~mm}$. Al., $7 \mathrm{~mm}$.; I $4-5 \mathrm{~mm}$. wide.

Female.-Differs from the male in having the front shining and lighter pilose, the dorsum shorter pilose, the abdomen entirely shining, and the third antennal joint much larger; in this sex it is enormousone and one-half times as large as in the male, but of the same shape.

Three specimens ; Moscow, Idaho; Prof. J. M. Aldrich.

This species is closely allied to $C$. Willistoni, but is specifically quite distinct in the larger size and different shape of the third antennal joint, in the fact that the arista is densely plumose, while in that species it is loosely so, and that in the male the abdomen is largely opaque. 
The third joint of the antennæ in C. Willistoni is small, subquadrate, and very much rounded at the tip ; in the present it is very large, subquadrate, and obtusely pointed at the tip.

Chilosia cyanea, n. sp.

Eyes bare, arista plumose, scutellum with bristles on the margin, third antennal joint subquadrate, a little longer than broad, bright reddish-yellow. Legs black.

Female.-Shining blue. Front slightly sulcate medially, shining black, distinctly punctate, black pilose. Face shining black, not pilose, almost imperceptibly pollinose, deeply concave below the antennæ (so that in profile the concavity recedes to the eyes), tubercle rounded, obtuse, projecting about as far as the middle of the third antennal joint, below the tubercle almost straight (so that a line from the apex of the antennal callosity parallel to the posterior eye margin would coincide with the outline of the face below the tubercle). Cheeks shining black, nearly bare. First and second antennal joints black, second reddish at the apex. Third joint of medium size, a trifle longer than wide, subquadrate, with the lower outer angle rounded, light reddish-yellow, light pollinose in some reflections. Arista at the extreme base of the joint black, incrassate for about one-half of its length, long loose plumose. Occiput olivaceous, lightly pollinose, superiorly black and inferiorly white pilose. Thorax shining blue, finely punctate in front, more coarsely so posteriorly and on the scutellum, with very short black pile, lengthened into slender bristles on the sides posteriorly and on the border of the scutellum. Scutellum entirely shining blue, its pile and that of the adjacent dorsum yellow (viewed from in front). Pleura shining, with light-coloured pile. Abdomen broadly ovate, widest at the apex of the second segment, everywhere shining blue, less strongly punctured than the scutellum, with short white pile that when viewed from above appears to form narrow oblique bands, meeting at the middle of the anterior margin of the segments. Tarsi and legs, except the knees, black. Wings hyaline, much longer than the abdomen, tegulæe and veins testaceous. Posterior cross-vein slightly incurved, apical cross-vein straight, with outward stump at base and about one-third of its length above. Length, $7 \mathrm{~T} / 2 \mathrm{~mm}$. Al., $8 \mathrm{~mm}$.

One specimen; Moscow, Idaho ; Prof. J. M. Aldrich.

This species is closely related to $C$. Willistoni, but may be separated from that species by the general colour and by the colour of the third antennal joint. 
Chilosia Aldrichi, n. sp. (Named after Prof. J. M. Aldrich.)

Eyes bare, arista scarcely pubescent, scutellum without bristles, legs black.

Female.-Shining black, almost bare. Front trisulcate, coarsely punctate, yellow pilose. Face shining on middle portion, powdered on the sides, between the lateral sutures and the eyes short pilose, below the antennæ deeply concave, below the tubercle slightly so. Tubercle round, projecting as far as the apex of the third antennal joint. Cheeks shining black, white pilose. Occiput shining olivaceous, light pilose. Ocellar area with a few black hairs. Antennal joints one and two black, third flattened, oval, slightly longer than broad, reddish-brown, darker above. Arista basal, almost bare, black, somewhat incrassate at base. Dorsum shining biack, lightly punctate, very sparsely short yellow pilose, humeri dark. Pleura shining, pilose like the dorsum. Scutellum black, shining, more strongly punctate than the dorsum. Abdomen oval, widest at the apex of the second segment, everywhere shining black; black pubescent in the middle, and short white pilose at the sides anteriorly. Legs black; front pairs, including the coxæ on the under side and posterior tarsi at apex, very indistinctly golden pubescent. Wings subhyaline, indistinctly tinged on the basal half with brownish, long, rather slender, veins brown. Apical cross-vein without stump, except at the base. Tegulæ white. Length, $9 \mathrm{~mm}$. Al., $8 \mathrm{~mm}$.

Three specimens ; Craig's Mt., Idaho ; Prof. J. M. Aldrich.

The colour of the third antennal joint in this species varies from very dark reddish to almost black.

TABLE OF NORTH AMERICAN SPECIES OF CHILOSIA.

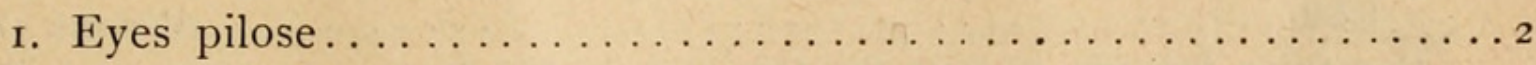

Eyes bare... ......................

2. Legs black......................... . . . . . . . .

At least the tibiæ more or less light-coloured $\ldots \ldots \ldots \ldots \ldots \ldots . . \ldots$

3. Third joint of the antennæ light reddish-yellow or yellow $\ldots \ldots \ldots 4$

Third joint of the antennæ black or reddish-brown $\ldots \ldots \ldots \ldots \ldots 5$

4. Abdomen shining (female), arista black . . . . . . . . . . 25

Abdomen largely opaque (female), arista brown $\ldots \ldots \ldots \ldots \ldots 28$

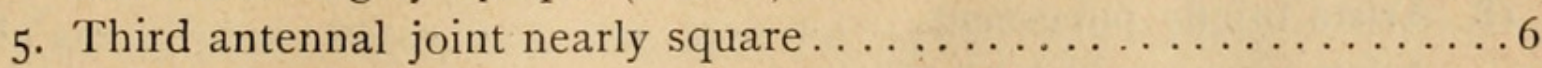

Third antennal joint rounded $\ldots \ldots \ldots \ldots \ldots \ldots \ldots \ldots \ldots \ldots \ldots \ldots \ldots \ldots \ldots$

6. Face in profile almost vertical below the antennæ, produced considerably below the eyes... 
Face strongly concave below the antennæ............ Baroni.

7. Shining portion of the abdomen steel-blue; pile of the front lightcoloured ............................ .

Shining portion of the abdomen metallic-green; pile of front

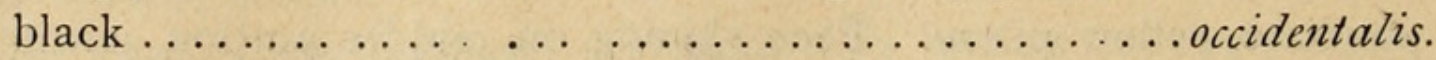

8. Legs black; at most, the knees lighter............... 9

Tibiæ at least largely yellow $\ldots \ldots \ldots \ldots \ldots \ldots \ldots \ldots \ldots \ldots \ldots$

9. Third antennal joint black ..................

Third antennal joint brown, yellow or reddish-yellow ......... 10

I0. Arista plumose $\ldots \ldots \ldots \ldots \ldots \ldots \ldots \ldots \ldots \ldots \ldots \ldots \ldots \ldots \ldots \ldots \ldots$

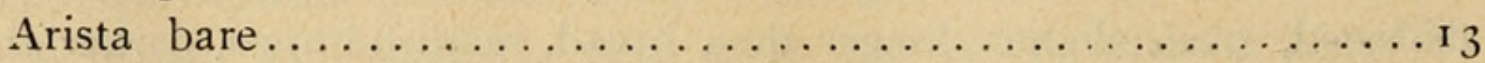

I I. Third antennal joint reddish-brown; arista loosely plumose ; general colour blackish; antennæ moderate in size (female).... Willistoni. Third antennal joint bright reddish-yellow . . ........... I 2

I 2. Arista densely plumose ; general colour blackish ; dorsum of thorax (female) yellowish pilose ; third antennal joint very large (female) ...................... signatiseta, n. sp.

Arista loosely plumose; general colour blue; dorsum of the thorax (female) not black pilose, but black pubescent (viewed from in

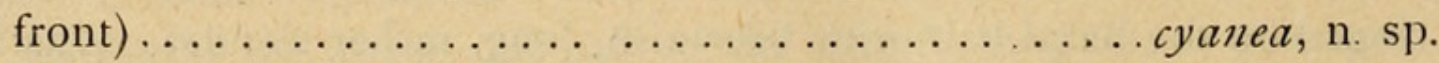

13. Third antennal joint reddish-brown or brown; rounded; tegulæ black ciliate ; wings blackish in front............nigripennis. Third antennal joint reddish-yellow, subquadrate; tegulæ white ciliate; wings not blackish in front............. versipellis.

I 4. Scutellum without bristles or bristlelike hairs on the margin .... I 5 Scutellum with bristles or bristlelike hairs on the margin ...... 8 I5. Posterior femora largely reddish, or at least so coloured at the base ............................ 3

Posterior femora, except the tip, always black........... 6

16. Abdomen entirely shining in both sexes................. comosa.

Abdomen, at least in the male, largely opaque $\ldots \ldots \ldots \ldots \ldots$ I 7

17. Four anterior tibiæ entirely yellow ; pile of front light-

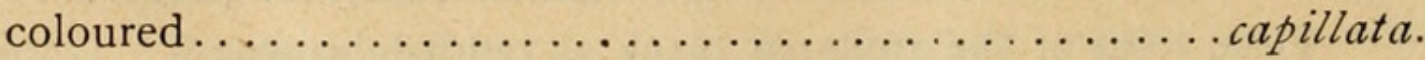

Four anterior tibiæ yellow only at apex and base; pile of front

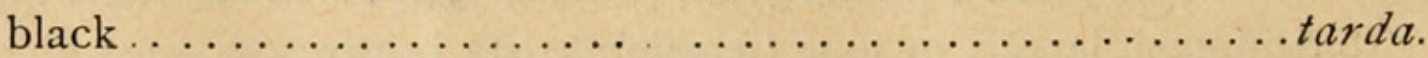

18. Arista briefly pubescent .................. 9

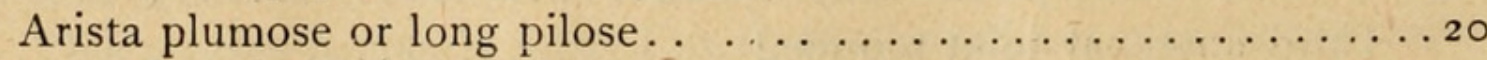

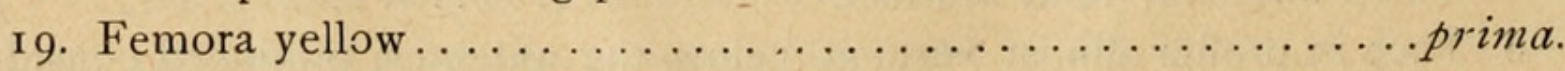

Femora largely black or brown $\ldots \ldots \ldots \ldots \ldots \ldots \ldots \ldots \ldots \ldots \ldots \ldots \ldots \ldots$ 
20. Third antennal joint quadrangular............. Townsendi. Third antennal joint rounded-ovate or ovate.......... $\mathrm{I}$

21. Abdomen in both sexes entirely shining .............. 6 Abdomen of the male largely opaque $\ldots \ldots \ldots \ldots \ldots \ldots \ldots 2$

22. Posterior femora on basal third, and at apex, yellow; scutellum yellow, except the narrow base................ pallipes. Posterior femora, except the apex, black; scutellum only piceous at apex ; first posterior cell broader and last section of fourth longitudinal vein accordingly longer................

23. Second abdominal segment partly opaque; four anterior tibiæ

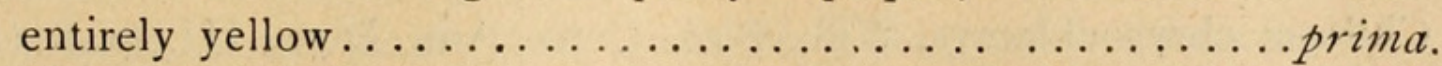
Abdomen entirely shining; four anterior tibiæ with at least a dark band parva.

24. Pile of dorsum of thorax black, abundant............ sorocula.

Pile of dorsum of thorax sparse, whitish or yellowish ........ 29

25. Thorax long pilose, third antennal joint moderate; arista

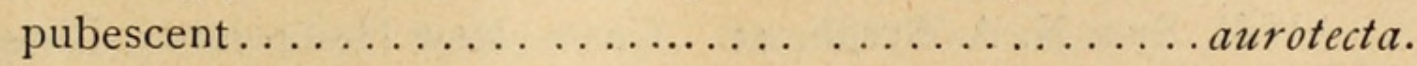

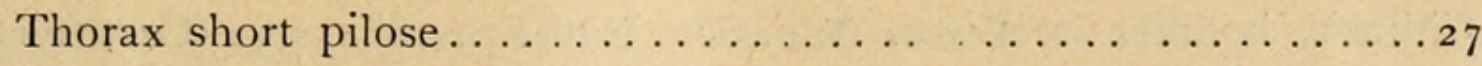

26. Anterior femora largely black.................. cyanescens.

Anterior femora yellow ......................

27. Scutellum with bristlelike hairs................. lcevis.

Scutellum destitute of such hairs .....................

28. Scutellum with bristles... .....................

Scutellum without bristles..................

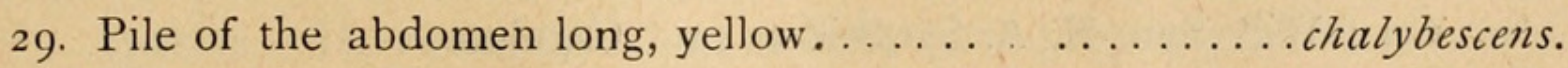

Pile of the abdomen short....................hoodiensis.

30. Posterior femora light-coloured at base and apex; dorsum of thorax smooth...............................

Posterior femora light-coloured only at the apex ; dorsum of thorax

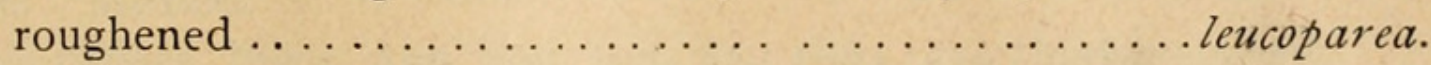

CATAlogue OF THE DESCRIBED NORTH AMERICAN SPECIES OF CHILOSIA. Chilosia.

Meigen ; Syst. Beschr. III., 296 (1822), Cheilosia.

Ibid., id., VII., I 23 ( 1838 ).

Cartosyrphus, Bigot, Ann. Soc. Ent. Fr., $1883 ; 555$. (Will.)

Melanogaster, Bigot, Ann. Soc. Ent. Fr., $1883 ; 25^{8}$. (Pt.)

Syrphus and Eristalis ex parte, auctorum. 
Chilosia Aldrichi, Hunter ante.

Chilosia aurotecta, Giglio-Tos ; Bulletino Mus. Zool. e. Anat. R. Univer., Torino; Vol. VII., I32, p. 4. (1892). Orizaba, Mexico.

Chilosia Baroni, Willist., Syn. N. A. Syrph. 40. ( 1886 ). Cala., Washington State.

Chilosia capillata, Loew, Centur. IV., 65 , $186_{3}$.-O. S. Cat. N. A. Dipt., I 878 , p. I 2 I ; Will. Syn. N. A. Syrph. 43. D. C.-Virginia. Cartosyrphus lamprurus, Bigot, Ann. Soc. Ent. Fr., I $884,55^{2}$ (Will.)

Chilosia chalybescens, Will., Kans. Uni., Quart. Vol. II., No. 2, I893. Cala.

Chilosia chrysochlamys, Wiil., Biol. Cent. Am. Dipt., III., p. 8 (r89r).

Omilteme, Mexico, and Sierra de las Aguas Escondidas, Mex.

Chilosia comosa, Loew, Cent. IV., 66, г 863.-O. S. Cat., I878, г 2 r., Will.

Syn. N. A. Syrph. 44. Colo., English River; Winnipeg.

Chilosia cyanea, Hunter ante. Idaho.

Chilosia cyanescens, Loew, Cent. IV., 66, I863.-O. S. Cat., I878, I 2 I.

Will. Syn. N. A. Syrph. 42. Conn.; New Hampshire; Illinois.

Chilosia hoodiensis, Bigot, Ann. Soc. Ent. Fr., I 884, $55^{2}$ (Cartosyrphus hoodianus). Will. Syn. N. A. Syrph. Appendix, 292. Oregon.

Chilosia lævis, Bigot, Ann. Soc. Ent. Fr., I883, $55^{2}$ (Cartosyrphus). Will.

Syn. N. A. Syrph. Ap. 292. Washington State.

Chilosia lasiopthalma, Will., Proc. Am. Phil. Soc. XX, 306, 1882. Ibid. Synopsis, 40, I886. Colorado.

Chilosia leucoparea, Loew, Cent. IV., $69-$ O. S. Cat. N. A. Dipt., I878, I 2 I ; Will. Syn. N. A. Syrphidæ, 45. Carolina.

Chilosia lucta, Snow, Kans. Uni., Quart. Vol. III., 228, April, I895. Colorado.

Chilosia nigripennis, Will., Proc. Am. Phil. Soc. XX., 307 ; I882. Oregon. Cartosyrphus infumatus, Bigot, Ann. Soc. Ent. Fr, I884, 553 .

Chilosia occidentalis, Will., Proc. Am. Phil. Soc. XX., 305. Ibid. Synopsis, 4I. California.

Chilosia pallipes, Loew, Cent. IV., 70, 1863.-O. S. Cat. N. A. Dipt., I 878, 12 I. Will. Synopsis, 4I, Ib. Appendix, 293. White Mts.; Washington, Cala.

Chilosia parva, Will., Proc. Am. Phil. Soc. XX., 307 ; 1883 . Oregon.

Melanogaster ochripes, Bigot, Ann. Soc. Ent. Fr., 1884, 555. (Will.)

Chilosia petulca, Will., Synopsis 39, I886. Snow, Kans. Uni., Quart. Vol. III., 228. State of Washington; Colorado. 
Chilosia plumata, Loew, Cent. IV., 68, г863-O. S. Cat.N. A. Dipt., 1878 , I2 I. Will. Synopsis, 42, I886. Virginia.

Chilosia prima, Hunter, Can. Ent. XXViII., 92, I896. Pennsylvania. Chilosia signatiseta, Hunter ante. Idaho.

Chilosia sorocula, Will., Biol. Cent. Am. Dipt. III., r89r. Snow, Kans. Uni., Quart. III., 228. Mexico : Omilteme, 8,000 feet ; Xucumanatlan, 7,000 feet ; Sierra de las Aguas Escondidas, 7,000 feet ; -all in Guerrero, U. S., New Mexico.

Chilosia sororia, Will., Biol. Cent. Am. Dipt. III., 9, r89 I. Mexico. Ciudad in Durango, 8, 100 feet.

Chilosia tarda, Snow, Kans. Uni., Quart. Vol. III., 228. Colorado.

Chilosia Townsendi, Hunter, Can. Ent., Vol. XXVIII., 94, 1896 .

California. Chilosia sp., ? Townsend, Dipt. Baja, Cala., in Proc.

Cala. Acad. Sci. Series ii., Vol. 4, 6r r:

Chilosia tristis, Loew, Cent. IV., 7 7 , I863--O. S. Cat. N. A. Dipt., I878, I 2 I. Will. Synopsis, 4r. Red River. (Loew.)

Chilosia versipellis, Will., Synopsis 44. State of Washington.

Chilosia Willistoni, Snow, Kans. Uni,, Quart. Vol. III., 227 (1895).

Cala.; Col. This species was described as C. lugubris by WillistonSynopsis, p. 45, I886. Snow has suggested the present name because "the name lugubris is preoccupied for a Swedish Chilosia by Zetterstedt." According to Herr T. H. Becker, Zetterstedt's species will not stand, as the types of that species are partly teneral forms of a well-known species of Meigen and partly mature specimens of other species. However, this does not affect the propriety of Mr. Snow's suggestion which I have adopted.

\section{SPECIES NOT INCLUDED ABOVE.}

Chilosia frontosa, Bigot, Ann. Soc. Ent. Fr., I883, 552. Will. Synopsis, p. 46. Mexico.

Chilosia rufipes, Bigot, Ann. Soc. Ent. Fr., I884, 555 (Melanogaster).

It is quite probable that this species is a Chilosia, from the fact that Mr. Bigot, in his table for the separation of the genera of Syrphidæ, distinguishes Melanogaster from Cartosyrphus by the fact that in the former genus, "Face, female, pourvue de sillons lateraux."

It will be impossible to recognize the species from the description, as the three very important characters-the bareness or pilosity of the eyes and arista, and the presence or absence of bristles on the scutellum-are entirely omitted.-North America (Bigot).

Chilosia, n. sp.? Snow, Kans. Uni., Quart. Vol. III., 229. Colorado. 


\section{$2 \mathrm{BHL}$ Biodiversity Heritage Library}

Hunter, W. D. 1896. "A summary of the members of the genus Chilosia, Meig., in North America, with descriptions of new species." The Canadian entomologist 28, 227-233. https://doi.org/10.4039/Ent28227-9.

View This Item Online: https://www.biodiversitylibrary.org/item/22111

DOI: https://doi.org/10.4039/Ent28227-9

Permalink: https://www.biodiversitylibrary.org/partpdf/29481

\section{Holding Institution}

MBLWHOI Library

\section{Sponsored by}

MBLWHOI Library

\section{Copyright \& Reuse}

Copyright Status: NOT_IN_COPYRIGHT

This document was created from content at the Biodiversity Heritage Library, the world's largest open access digital library for biodiversity literature and archives. Visit BHL at https://www.biodiversitylibrary.org. 